\title{
Copper-transporting P-type adenosine triphosphatase (ATP7A) is associated with platinum- resistance in non-small cell lung cancer (NSCLC)
}

\author{
Zhuang-hua Li ${ }^{1,3+}$, Miao-zhen Qiu' ${ }^{1,2+}$, Zhao-lei Zeng ${ }^{1}$, Hui-yan Luo ${ }^{1,2}$, Wen-jing Wu ${ }^{1,2}$, Feng Wang ${ }^{1,2}$, \\ Zhi-qiang Wang ${ }^{1,2}$, Dong-sheng Zhang ${ }^{1,2}$, Yu-hong $\mathrm{Li}^{1,2}$ and Rui-hua $\mathrm{Xu}^{1,2^{*}}$
}

\begin{abstract}
Background: Copper export protein ATP7A is important for maintaining copper homeostasis. Recent studies have shown that copper transporters are also involved in the transport of platinum. The goal of this study was to determine the role of ATP7A in the platinum-resistance of non-small cell lung cancer (NSCLC).

Methods: Sensitivities to platinums were detected by MTT assay and drug-resistance related genes were analyzed by real-time PCR and immunoblotting between DDP-sensitive A549 and the corresponding DDP-resistant cell subline (A549/DDP). ATP7A expression was evaluated by immunohistochemistry in tumor tissues of unresectable NSCLC patients who received cisplatin-basing chemotherapy.

Results: The expression of ATP7A was significantly higher in A549/DDP cell subline than in A549 cells at both mRNA and protein levels. The silencing of ATP7A expression in A549/DDP by siRNA partially reversed DDPresistance (29.62\%) and increased cell apoptosis. ATP7A expression was detected in 41.6\%of NSCLC patients, but not in adjacent stroma nor normal lung tissues. ATP7A-positive patients had a significantly poorer histological grade $(p=0.039)$ and poorer response to platinum-basing chemotherapy $(p=0.001)$ compared with ATP7Anegative patients. Cox's proportional hazards analysis showed that ATP7A expression was an independent prognostic factor for overall survival $(p=0.045)$.
\end{abstract}

Conclusions: ATP7A overexpression played an important role in platinum-resistance of NSCLC, and was a negative prognostic factor of NSCLC patients treated with platinum-based chemotherapy.

\section{Background}

Non-small cell lung cancer(NSCLC) accounts for $80 \%$ of all lung cancers and is a leading cause of cancer-related death during the last decades. Platinum-based chemotherapy is the major treatment for advanced NSCLC. However, the best overall response rate is only $30-50 \%$ [1]. The intrinsic/acquired resistance of tumor to platinum derivates limit the effectiveness of therapy [2]. Consequently, there is great need for elucidating the mechanism of resistance to platinum in NSCLC.

There are a viariety of factors contributing to platinum-resistance, including decreased drug accumulation,

\footnotetext{
* Correspondence: xurh@sysucc.org.cn

† Contributed equally

'State Key Laboratory of Oncology in South China, Sun Yat-Sen University

Cancer Center, Guangzhou 510060, China

Full list of author information is available at the end of the article
}

enhanced detoxification, and increased DNA repair efficiency [3]. Although multidrug resistance-associated protein 2 (MRP2/ABCC2) has been reported to transport DDP and confered resistance to DDP [4], actually the mechanisms of decreasing of DDP accumulation in resistant cancer cells have not been fully elucidated yet. One of the mechanisms might be the vesicular transport depending on copper transporters.

Copper uptake protein CTR1, copper export proteins ATP7A and ATP7B are important for maintaining copper homeostasis. Recent studies have shown that copper transporters are also involved in the transport of platinum. DDP-resistant cells showed cross-resistant to copper, and vice versa [5]. Evidences also suggested that some copper influx transporters especially CTR1 were involved in the cellular uptake of DDP, CBDCA and L-OHP, and the

\section{C) Biomed Central}


other two copper transporters ATP7A and ATP7B import copper to golgi apparatus which regulates the efflux of DDP [6]. As a P-type ATPase copper transporter, ATP7A is expressed in many tissues except for liver and sustains not only copper-dependent tyrosinase in melanosomes [7] but also dopamine beta monooxygenase, lysl oxidase and copper containing protein. ATP7B has been reported to relate to DDP-resistance first $[8,9]$. Then, another copper transporter ATP7A has also been implicated in platinumresistance later $[10,11]$.

Nevertheless, it is generally accepted that platinumresistance most likely has multiple mechanisms and the mechanisms of resistance may differ depending on the cell types [12]. Whether NSCLC shares common drug resistance mechanisms with other cancers or possesses its own distinct characteristics is still unclear. Hence, a better understanding of the active mechanism of platinum-resistance in NSCLC may lead to new treatment strategies and allow selection of patients for specific treatment modalities.

\section{Methods}

\section{Drugs}

DDP and CBDCA were purchased from Bristol-Myers Squibb (NY, USA), and L-OHP was provided by Sanofiaventis (Paris, France). DDP and CBDCA were diluted and stored according to the method described [13]. $\mathrm{L}-\mathrm{OHP}$ was diluted in water stored as a $12.6 \mathrm{mM}$ stock solution at $-20^{\circ} \mathrm{C}$.

\section{Cell Lines and Cell Culture}

Human NSCLC cell lines included the parental cell line A549 and the cell subline A549/DDP which was resistant to DDP. All the cells were generously provided by State Key Laboratory of Oncology in Southern China and were all cultured according to the method described [13]. Cells used for the experiments were in the logarithmic phase of growth.

\section{MTT Assay}

The cytotoxicities of DDP, CBDCA and L-OHP were determined by MTT assay according to the method described [14]. The dose-response curve could be plotted with $50 \%$ inhibitory concentration $\left(\mathrm{IC}_{50}\right)$. Resistance index (RI) was calculated as $\mathrm{IC}_{50}$ resistant/IC $\mathrm{I}_{50}$ sensitive cell line.

\section{Real-time PCR}

The mRNA expressions of ATP7A in A549 and A549/ DDP cells were determined using real-time PCR according to the method described [15]. Briefly, total RNA from cultured cells was extracted by using the Trizol reagent (Invitrogen) according to the manufacturer described, and cDNAs were amplified and quantified in
ABI Prism 7500 Sequence Detection System (Applied Biosystems) by using dye SYBR Green I (Invitrogen). The sequence was as following: ATP7A, forword: 5'GCCTGCGTACGTGGATTTAT-3' and reverse: 5'TCAATGGTCCAAACACAGGA-3'. GAPDH was used as an internal control (forward: 5'-ACCA-CAGTCCATGCCATCAC-3' and reverse: 5'-TCCACCACCCTGTTGCTGTA -3').

\section{Immunoblotting}

The protein expressions of ATP7A and GAPDH were determined using immunoblotting according to the method described [14]. Primary antibodies were diluted in a blocking solution 1: 500 for ATP7A (Abcam, Cambrige, UK) and 1:5000 for GAPDH (Boster, Wuhan, China).

\section{siRNA Transfection}

ATP7A siRNA sequences were targeted exon 11 (sense, GCAACUAUUGUAACUCUUG dTdT; antisense, CAAGAGUUACAAUAGUUGC dTdT) [16]. A nonsilencing siRNA sequence, shown by BLAST search which did not share sequence homology with any known human mRNA was used as control for ATP7A-targeting experiments. The siRNA sequences were synthesized by Guangzhou RiboBio (Ghuangzhou, China). The transfection of siRNA was performed using lipofectamine-2000 (Invitrogen, CA, USA) according to the manufacturer's recommendation. Oligofectamine/siRNA complexes were formed in serum free DMEM by adding siRNA (25, 50 or $100 \mathrm{nM}$ final concentration) to $5 \mu \mathrm{l}$ of Oligofectamine (Invitrogen, CA, USA) per well. Complexes were allowed to form at $25^{\circ} \mathrm{C}$ for $10 \mathrm{~min}$ and added to wells $(500 \mu \mathrm{l}$ per well). After 4 hours of transfection, the culture medium containing $10 \%$ serum was added. The assays were carried out $24,48,72$ and 80 hours post transfection.

\section{Intracellular accumulation of DDP}

For the characterization of DDP uptaking, $1 \times 10^{6}$ cells were seeded in $100 \mathrm{~mm}$ tissue culture dishes and transfected with siRNA_ATP7A and siRNA_Control by lipofatamine 2000, $36 \mathrm{hrs}$ later exposed to $60 \mu \mathrm{M}$ freshly prepared DDP. After 12 hrs of exposure to the drugs, the media was discarded quickly and the cells were washed three times with $5 \mathrm{ml}$ ice-cold PBS buffer. Then cells were trypsinized, scraped and resuspended in fresh drugfree medium and centrifuged at 1,000 rpm for 5 mins. The supernatant was discarded and the pellet was washed twice in $1 \mathrm{ml}$ ice-cold PBS buffer. After centrifugation for 2 mins at $4^{\circ} \mathrm{C}$ and $6,000 \times \mathrm{g}$ the supernatant was discarded again and the cell pellet was frozen at $-20^{\circ} \mathrm{C}$ until analysis. Immediately after thawing, the cells were lysed with concentrated nitric acid for 20 mins in the water 
bath at $60^{\circ} \mathrm{C}$. The lysed samples were then diluted to 3.5 $\mathrm{ml}$ of distilled water and intracellular platinum $(\mathrm{Pt}) \mathrm{con}$ centrations were measured by the atomic spectrometer (Varian AA Duo, USA). Pt levels were expressed as $\mu \mathrm{M} / 1$ $\times 106$ cells, with the cell number determined by counting (Nexcelom Cellometer Auto T4 cell counter, USA) in parallel cultures. Experiments were performed in duplicate and the values expressed were the means \pm SD of the three independent experiments.

\section{Flow Cytometry}

Apoptotic or necrotic cell death was determined by flow cytometric analysis of cells double stained with Annexin V-FITC and propidium iodide (PI) using an assay kit from KeyGen Biotech (Nanjing, China). A549/DDP cells were plated into 6-well plates and adhered for overnight. Then $100 \mathrm{nM}$ final concentration of siRNA (targetedATP7A or nonsilencing siRNA) was added to wells for transfection. After 80 hours of transfection including 72 hrs for DDP incubation, cells were collected, washed with cold PBS, and suspended in binding buffer. The cells were stained with Annexin V-FITC and PI for 15 minutes at room temperature in the dark. The samples were analyzed with a flow cytometry (BECKMANCOULTER FC500, CA, USA).

\section{Patients and Samples}

Between October 2006 and August 2008, the medical records of pathology-proven unresectable (local advanced or distant metastasis) non-small cell lung cancer patients who were diagnosed and received cisplatinbased chemotherapy in the Cancer Center of Sun YatSen University were retrospectively analyzed. We excluded patients who had a history of other primary cancers. Patients who were considered for the final analysis should have a performance status (PS) of grade 0 or 1 and didn't undergo surgery or radiotherapy, but was primarily treated with first-line cisplatin-based chemotherapy. We totally identified 89 formalin-fixed paraffin-embedded samples, corresponding to pretreatment bronchoscopic or fine-needle aspiration biopsies. Diagnosis was based on conventional morphological examination of the sections stained with H\&E staining, and staging of tumors were classified according to the UICC classification. The cisplatin-based regimen included cisplatin $\left(75-80 \mathrm{mg} / \mathrm{m}^{2}\right)$, paclitaxel $\left(175-225 \mathrm{mg} / \mathrm{m}^{2}\right)$, or gemcitabine $\left(800-1000 \mathrm{mg} / \mathrm{m}^{2}, \mathrm{~d} 1, \mathrm{~d} 8\right)$ or navelbine $(25$ $40 \mathrm{mg} / \mathrm{m}^{2} \mathrm{~d} 1, \mathrm{~d} 8$ ). All of the cases received 1-6 courses cisplatin containing regimens. Response to cisplatinbased chemotherapy was evaluated by physicians according to Response Evaluation Criteria in Solid Tumors (RECIST) criteria. The follow-up for all of the patients was updated in June 1, 2009 (median follow-up time was 12.5 months; range, 1.7-32 months). As of the last follow-up time, all patients had died of tumor progression. The study was approved by the institutional review board of the hospital.

\section{Immunohistochemical Staining}

Immunohistochemical staining was performed according to the guidelines of the Catalyzed Signal Amplification System (ZSGB-BIO, Beijin, China). The slides were incubated with a 1:200 dilution of anti-ATP7A antibody (Abcam, Cambrige, UK). Adult normal kidney and lung samples were taken as positive control and negative control respectively. The slides were examined and scored by two pathologists independently without knowledge of clinical information of the patients. If more than $10 \%$ of the tumor cells were stained, the samples were considered to be ATP7A-positive carcinomas [17].

\section{Statistical Analysis}

Data analysis was performed using SPSS 16.0 statistical software package (SPSS, IL, USA). Continuous variables were analyzed using Student's $t$ test. As qualitative variables, the clinicopathologic characteristics of 89 patients with NSCLC were analyzed using chi-square test. Survival curves were determined using Kaplan-Meier method, and differences in survival between subgroups were compared with log-rank test. Multivariate prognostic analysis was performed using Cox proportional hazards model. All the reported P-values were two-sided. $P<$ 0.05 was hypothesized to be significant.

\section{Results}

A549/DDP cells is resistant to platinum-derivate drugs

The drug sensitivities of A549 and A549/DDP cells to three platinum-derivate drugs (DDP, CBDCA and L$\mathrm{OHP}$ ) were shown in Table 1 . The $\mathrm{IC}_{50}$ were 3.79 and $29.83 \mathrm{uM}$ for DDP, 45.85 and $205.70 \mathrm{uM}$ for CBDCA, 7.68 and $18.07 \mathrm{uM}$ for L-OHP in A549 and A549/DDP respectively. Compared with A549 cells, A549/DDP showed 7.88 folds enhanced resistance to DDP, and both exhibited cross-resistance to CBDCA and L-OHP (4.49 and 2.35 folds respectively). RIs were the highest for DDP and the lowest for L-OHP.

\section{ATP7A was overexpressed in A549/DDP}

The expression of ATP-binding cassette $(\mathrm{ABC})$ transporters in A549 and A549/DDP cell lines were examed by real-time PCR and immunoblotting. As shown in Figure 1a, ATP7A mRNA expression in A549/DDP was much higher than in A549 (Figure 1a) and the protein expression was also comfirmed by immunoblotting. There was no significant difference in expressions of MDR1, ABCG2, MRP1, LRP, GST-pi, DNApol $\beta$, CTR1 and ATP7B (data not shown). These results indicated 
Table 1 Drug sensitivity of A549 and A549/DDP cells to platinum derivatives (DDP, CBDCA and L-OHP)

\begin{tabular}{|c|c|c|c|c|}
\hline \multirow[b]{2}{*}{ Drugs } & \multicolumn{4}{|c|}{${ }^{\mathrm{a}} \mathrm{I} C_{50}($ mean $\pm \mathrm{SD}, \mathrm{uM})$} \\
\hline & A549 & A549/DDP & ${ }^{\mathrm{b}} \mathrm{RI}$ & $P$ \\
\hline DDP & 3.79 & 5 & 38 & $<0.001$ \\
\hline CBDCA & $45.85 \pm 1.24$ & 205.7 & 9 & $<0.001$ \\
\hline L-OHP & $7.68 \pm 0.28$ & $18.07 \pm 0.39$ & 2.35 & $<0.001$ \\
\hline \multicolumn{5}{|c|}{$\begin{array}{l}\text { Cells were precultured for } 24 \text { hrs at a density of } 5^{*} 10^{3} \text { cells/well in } 96 \text {-well } \\
\text { multiplates.Cytotoxicity was determined } 72 \text { hrs after drug exposure by MTT. a } \\
I_{50} \text {, inhibitory concentration that kills } 50 \% \text { of cell population. Data represent } \\
\text { the mean } \pm \text { SD of at least three independent experiments performed with } 8 \\
\text { wells at each drug concentration tested. b, RI, resistance index calculated as } \\
I_{50} \text { resistant/IC } 50 \text { sensitive cell line. SD, standard deviation; DDP, cisplatin; } \\
\text { CBDCA, carboplatin; L-OHP, oxaliplatin. P } P 0.05 \text { was considered as a } \\
\text { significant change in drug sensitivity (Student's t-test) }\end{array}$} \\
\hline
\end{tabular}

that ATP7A might be related to the platinum-derivates resistance in A549/DDP cells.

Inhibition of ATP7A expression by siRNA enhance chemosensitivity to DDP in A549/DDP

To further determine the role of ATP7A in platinumresistance of A549/DDP cells, we used RNA interference system to knockdown the expression of ATP7A in A549/DDP cells. As shown in Figure 2, $100 \mathrm{nM}$ ATP7A-targeted siRNA sequences, the silenced most expression of ATP7A protein in A549/DDP cells (76.0 \pm $0.08 \%)$. The reversal effect of the siRNA transfection (100 nM, $80 \mathrm{hrs)}$ on the DDP-resistance of A549/DDP was investigated by MTT assay. As shown in Table 2, siRNA transfection targeting ATP7A reduced $\mathrm{IC}_{50}$ of A549/DDP cells significantly compared with controls (reversal effects of 29.62\%). Silencing ATP7A was able to partially reverse DDP-resistance in A549/DDP cells. These results indicated that ATP7A played an important role in the modulation of platinum-resistance in A549/ DDP.

To further determine whether ATP7A-targeted siRNA transfection could reverse the platinum-resistance of A549/DDP, DDP-induced apoptosis was detected by

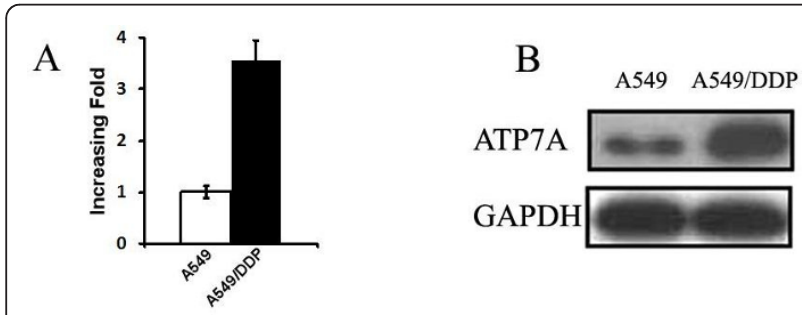

Figure 1 Expression of ATP7A at RNA and protein levels in A549 and A549/DDP cells. a, total of RNA isolated from A549 and A549/DDP cells was subjected to real-time PCR for ATP7A b, ATP7A protein expression was determined by Western-blot analysis using anti-ATP7A antibody. Equal loading was confirmed with GAPDH as a control in real-time PCR and Western-Blot.

\section{UN Con ATP7A_siRNA _SiRNA 25nM 50nM $100 \mathrm{nM}$}
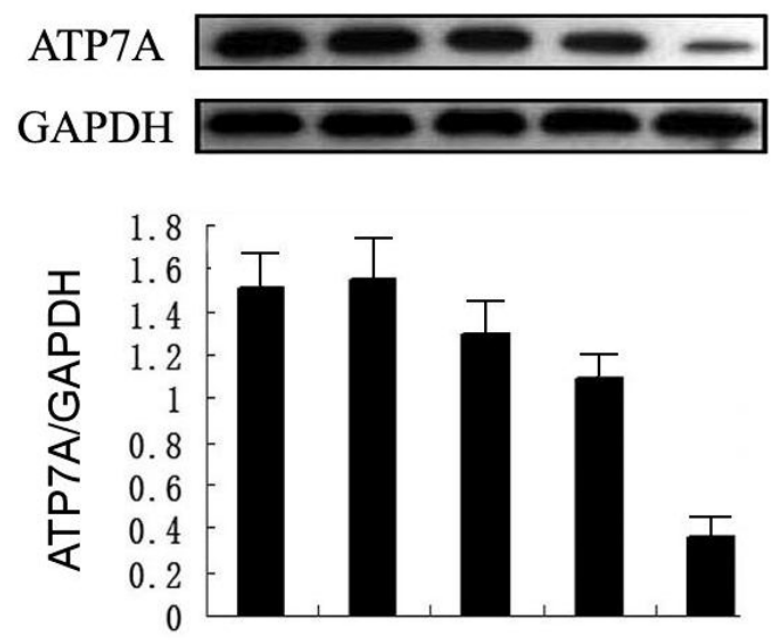

Figure 2 Effect of ATP7A-siRNA $80 \mathrm{~h}$ on ATP7A protein expression in A549/DDP ells. Equal loading was confirmed with GAPDH as a control. Western blot analysis of ATP7A in A549/DDP cells following treatment with control siRNA and different concentrations of targeted ATP7A siRNA ( $25 \mathrm{nM}, 50 \mathrm{nM}$ and 100 nM) for 80 h. Protein expression was quantified by Quantity One software. Results are the representative of three similar experiments.

Annexin V-PI assay. As shown in Figure 3, without DDP, there was little apoptosis and no significant difference between ATP7A-targeted siRNA group and control siRNA group. But after treatment with different concentrations of DDP for $72 \mathrm{hrs}$, cell apoptotic rates in ATP7A siRNA group were significantly higher than in control siRNA group $(28.37 \pm 1.25 \%$ compared to 16.43 $\pm 1.40 \%$ at $30 \mathrm{uM} \mathrm{DDP}$ and $48.33 \pm 2.16 \%$ compared to

Table 2 Partially reversal effect after ATP7A's silence by siRNA for $80 \mathrm{~h}$ in the DDP-resitant subline A549/DDP

\begin{tabular}{cccc}
\hline cell lines & $\begin{array}{c}\mathbf{I C}_{\mathbf{5 0}} \text { (mean } \pm \mathbf{S D}, \\
\mathbf{u M})\end{array}$ & $\begin{array}{c}\text { a } \text { reversal effect } \\
\text { (\%) }\end{array}$ & $\boldsymbol{P}$ \\
\hline A549/DDP & $29.33 \pm 0.20$ & & \\
\hline $\begin{array}{c}\text { A549/DDP Control } \\
\text { SiRNA }\end{array}$ & $29.51 \pm 0.17$ & & $>0.05$ \\
\hline $\begin{array}{c}\text { A549/DDP ATP7A } \\
\text { SiRNA }\end{array}$ & $20.77 \pm 0.28$ & 29.62 & $<0.001$ \\
\hline
\end{tabular}

ATP7A siRNA group is A549/DDP cells treated with ATP7A siRNA sequences at the final $100 \mathrm{nM}$ concentration for $8 \mathrm{hrs}$ and then added DDP at various concentrations for 72 hrs. Control siRNA group is A549/DDP cells treated with nonsilencing siRNA sequences at the final $100 \mathrm{nM}$ concentration for $8 \mathrm{hrs}$ and then added DDP at various concentrations for $72 \mathrm{hrs}$. a, reversal effect was determined by the percentage of the $\mathrm{IC}_{50}$ difference between Control siRNA group and ATP7A siRNA group to the IC $\mathrm{C}_{50}$ of Control SiRNA groups. Data represents the mean \pm SD of at least three independent experiments performed with 8 wells at each drug concentration tested. $P<0.05$ was considered as a significant change in drug sensitivity (Student's t-test). SD, standard deviation; DDP, cisplatin 


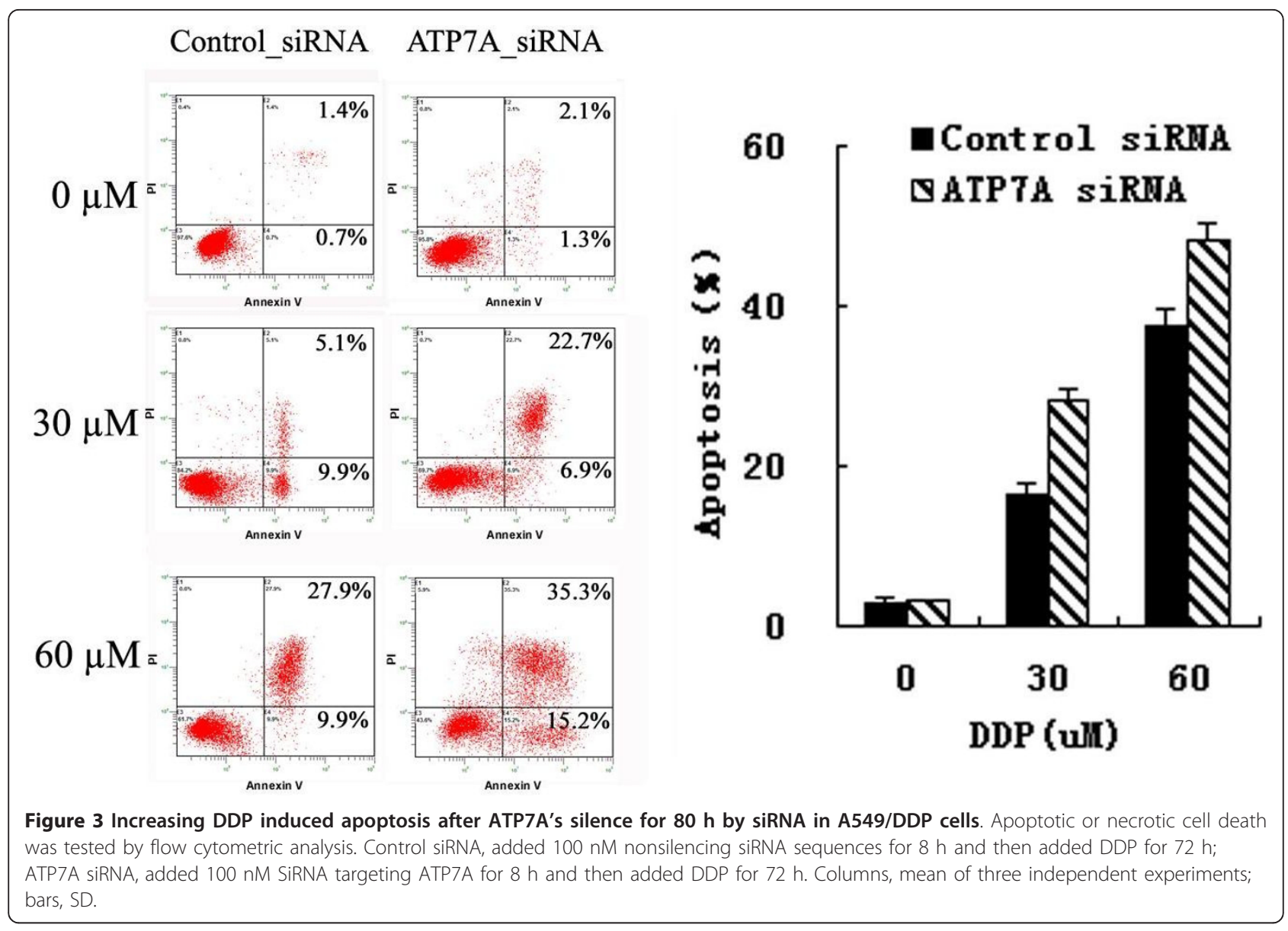

$37.43 \pm 2.17$ at $60 \mathrm{uM}$ DDP). Thus, silence of ATP7A by siRNA enhanced DDP-induced apoptosis significantly compared with control siRNA at different DDP concentrations $(P<0.01)$. These results 'further confirmed that ATP7A played a role in modulation of platinum-resistance in A549/DDP cells.

Effect of ATP7A on the intracellular accumulation and efflux of platinum

To investigate how does ATP7A modulated platinum resistance, cellular accumulation of DDP was examined in A549, A549/DDP and A549/DDP cells transfected with siRNA ATP7A or siRNA control. Cells were incubated in medium containing $60 \mu \mathrm{M}$ freshly prepared DDP for $12 \mathrm{hrs}$ and the level of DDP in cell lysates was then measured. As shown in Table 3, intracellular amounts of DDP in A549/DDP cells transfected with siRNA control $\left(0.06 \pm 0.005 \mathrm{uM} / 10^{6}\right.$ cells $)$ were much lower than in the parental A549 cells $(0.69 \pm 0.007 \mathrm{uM} /$ $10^{6}$ cells) $(p<0.001)$. and intracellular amounts of DDP in A549/DDP cells transfected with siRNA ATP7A (0.13 $\pm 0.003 \mathrm{uM} / 10^{6}$ cells) were significantly higher than in A549/DDP cells transfected with siRNA control $(p<$
0.001). These data strongly suggested that the decreased DDP accumulation in A549/DDP cells was due to an ATP-dependent DDP transporting activity of ATP7A, which mediated platinum-resistance.

ATP7A expression was negatively correlated with response to DDP-based chemotherapy in NSCLC

To investigate the expression of ATP7A in NSCLC tissue, and analyze its correlation to the clinicopathologic features and prognosis of NSCLC, immunohistochemistry method

Table 3 Intracellular accumulation of DDP in A549 cells, A549/DDP cells and A549/DDP cells treated with control siRNA or ATP7A siRNA respectively

\begin{tabular}{ccc}
\hline cells & Concentration $\left(\boldsymbol{\mu m o l} / \mathbf{1 0 ^ { 6 }}\right.$ cells) & $P$ \\
\hline A549 & $0.69 \pm 0.007$ & \\
\hline A549/DDP & $0.06 \pm 0.002$ & $<0.001$ \\
\hline A549/DDP_Control_siRNA & $0.06 \pm 0.005$ & \\
\hline A549/DDP_ATP7A_siRNA & $0.13 \pm 0.003$ & $<0.001$ \\
\hline
\end{tabular}

Pt levels were expressed as $\mu \mathrm{mol} / 1 \times 10^{6}$ cells (A549 cells, A549/DDP cells and A549/DDP cells treated with control siRNA ATP7A siRNA). Experiments were performed in duplicate and the values expressed were the means $\pm S D$ of the three independent experiments 
were employed. As shown in Figure 4, ATP7A was detected in cytoplasmic staining of tumor cells in 37 of 89 (41.6\%) tumors but not in adjacent stroma nor normal lung tissue. Associations were sought between ATP7A expression and the clinicopathologic characteristics of 89 patients including age, gender, stage, performance status (PS), histological subtype, histological grade, serum Carcinoembryonic Antigen (CEA) status, response to chemotherapy and overall survival (OS). The clinical parameters of the 89 patients in this study were summarized in Table 4. ATP7A expression was negatively correlated with response to DDP-basing chemotherapy $(P=$ $0.001)$ and histological grade $(P=0.039)$. No significant association was found between ATP7A expression and age $(P=0.469)$, gender $(P=0.442)$, stage $(P=0.436)$, PS $(P=$ $0.361)$, histological subtype $(P=0.67)$ and serum CEA status $(P=0.661)$. The median overall survival $(\mathrm{mOS})$ of all patients was 12.53 months. In 37 patients with ATP7A positive staining, the mOS was 11.03 months, and the mOS was 14.02 months in 52 patients with ATP7A negative staining. As shown in Figure 5, Kaplan-Meier analysis indicated that ATP7A positive patients had inferior survival compared with ATP7A negative patients $(P=0.021$, log-rank test). In univariate analysis, ATP7A, stage, PS, serum CEA status and histological grade were significantly correlated with survival $(P=0.021,0.019,0.004,0.022$ and 0.013 respectively). Cox's proportional hazards model analysis showed that 4 independent factors significantly related to overall survival: ATP7A $(\mathrm{RR}=1.570,1.010$ $2.440, P=0.045)$, stage $(\mathrm{RR}=1.759,1.256-2.464, P=$ $0.001)$, CEA status $(\mathrm{RR}=1.828,1.162-2.874, P=0.009)$ and histological grade $(\mathrm{RR}=1.704,1.205-2.408, P=0.003)$.

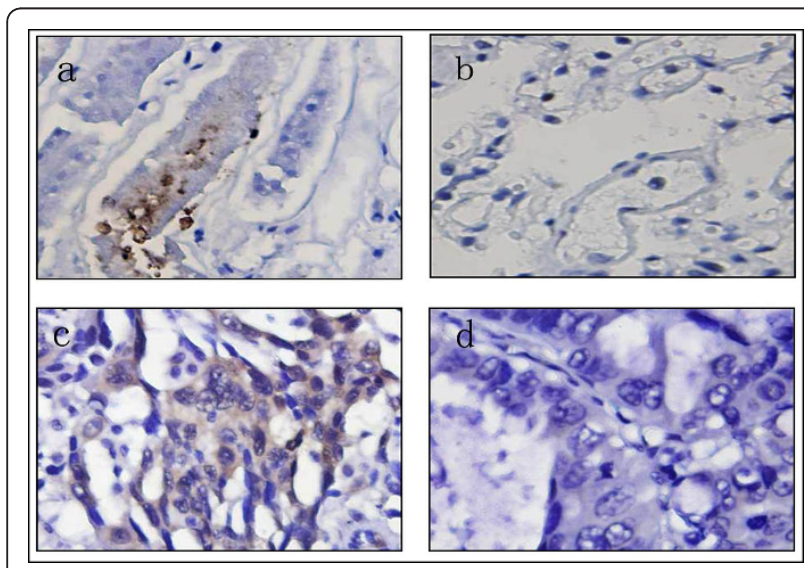

Figure 4 Immunohistochemical staining of normal and NSCLC human tissues for ATP7A (magnification, $\times 400$ ). a, adult normal kidney tissue as positive control; $b$, adult normal lung tissue as negative Control; c, ATP7A high positive case, almost all of tumor cells showed strong positive reaction in the cytoplasm; $d$, ATP7A negative case, ATP7A expression was not detectable in the cytoplasm.
Table 4 The clinicopathologic characteristics of 89 patients with NSCLC treated with platinum-based chemotherapy only in this study

\begin{tabular}{|c|c|c|c|c|}
\hline \multirow[t]{2}{*}{ Characteristics } & \multicolumn{4}{|c|}{ Number of patients } \\
\hline & Total & ATP7A(-) & ATP7A(+) & $P$ \\
\hline \multicolumn{5}{|l|}{ Age } \\
\hline median & 57 & 57 & 57 & \\
\hline range & $31-79$ & $35-79$ & $31-77$ & 0.469 \\
\hline \multicolumn{5}{|l|}{ Gender } \\
\hline male & 64 & 39 & 25 & \\
\hline female & 25 & 13 & 12 & 0.442 \\
\hline \multicolumn{5}{|l|}{ Response to chemo } \\
\hline$P R$ & 29 & 24 & 5 & \\
\hline $\mathrm{SD}+\mathrm{PD}$ & 60 & 28 & 32 & 0.001 \\
\hline \multicolumn{5}{|l|}{ Stage } \\
\hline III & 48 & 28 & 20 & \\
\hline IV & 41 & 24 & 17 & 0.436 \\
\hline \multicolumn{5}{|l|}{ PS } \\
\hline 0 & 46 & 29 & 17 & \\
\hline$>0$ & 43 & 23 & 20 & 0.361 \\
\hline \multicolumn{5}{|l|}{ Histology } \\
\hline squamous & 25 & 14 & 11 & \\
\hline adenocarcinoma & 64 & 39 & 25 & 0.67 \\
\hline \multicolumn{5}{|l|}{ Grade } \\
\hline low & 48 & 28 & 20 & \\
\hline moderate & 27 & 12 & 15 & \\
\hline high & 14 & 12 & 2 & 0.039 \\
\hline \multicolumn{5}{|l|}{ CEA status } \\
\hline normal & 34 & 18 & 16 & \\
\hline elevated & 55 & 34 & 21 & 0.661 \\
\hline
\end{tabular}

\section{Discussion}

This article sheds new light on the potential function of copper transporter ATP7A in NSCLC. In our study, as expected, DDP-resistant cell subline (A549/DDP) was much more (7.88 folds) resistant to DDP than the parental cells (A549). Note that this cell line also exhibited cross-resistance to CBDCA (4.49 folds) and L-OHP (2.35 folds). The resistant indexes of L-OHP (2.352) was much lower than that of DDP (7.88). That could be caused by the chemical structure of L-OHP. L-OHP bears a 1,2-diaminocyclohexane $(\mathrm{DACH})$ ligand which is quite different from DDP and CBDCA, conferring it a markedly different spectrum of activity from DDP and CBDCA [18]. A549/DDP was exposed DDP by pulse treatment which is similar to the clinical pulse protocol for NSCLC patients to select for the drug-resistant subline. CBDCA and L-OHP were not exposed to A549/ DDP in the process of establishing the cell subline. We 


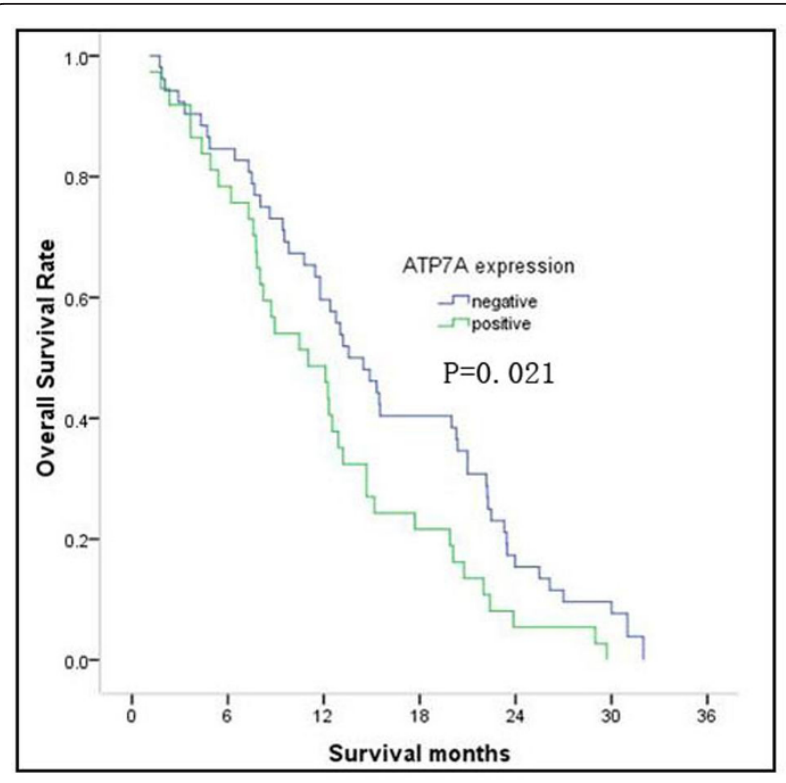

Figure 5 Overall survival curves of NSCLC treated with platinum-based chemotherapy. Comparison of survival curves for patients whose tumors stained positive for ATP7A with those patients whose tumors were classified as negative for ATP7A expression. Curves present the results for all patients. P value was conducted by Log-rank test.

found that ATP7A expression correlated with the resistance to DDP, then might at a lesser extent to CBDCA and L-OHP.

Reduced drug accumulation has been related to ATPbinding cassette $(\mathrm{ABC})$ transporters. Overexpression of MDR1(Pgp) was capable of pumping out a variety of diverse chemotherapy drugs to reduce intracellular drug concentration and multidrug resistance (MDR) [19], and A link was identified between MDR transporter Pgp, and MAPK signaling and invasion in human melanoma cells [20]. In clinical, MDR1 expression in childhood ALL is an independent adverse prognostic factor on outcome, a useful biological marker of response in these patients [21]. Recently, a report found that single nucleotide polymorphisms of $\mathrm{ABCC} 5$ and $\mathrm{ABCG} 1$ transporter genes correlated to irinotecan-associated gastrointestinal toxicity in colorectal cancer patients [22]. But in our study, the mRNA expression levels of MDR1, ABCG2, MRP1, LRP, GST-pi, DNApol $\beta$, CTR1 and ATP7B were almost the same between A549/DDP and A549 cells, suggesting that the platinum-resistance in A549/DDP cells is independent of $\mathrm{ABC}$ transporters. However, ATP7A expression in both mRNA and protein levels significantly increased in A549/ DDP cells comparing with the parental cells respectively. Furthermore, in A549/DDP cells, ATP7A siRNA knockdown $(76.0 \pm 0.08 \%)$ was able to partially reverse DDPresistance $(29.62 \%)$. The cytotoxicity of platinum- compounds was thought to be determined primarily by their DNA adducts [23], which then induced cell apoptosis [24]. In our study, ATP7A silencing significantly increased cells apoptosis rates in A549/DDP cells. Thus, the reduced expression of ATP7A achieved by siRNA knockdown resulted in enhancement of DDP-sensitivity and increased DDP-induced apoptosis. But there should be many factors related to the resistance to DDP in A549/DDP cells, but not only ATP7A. So it isn't surprising that knocking down ATP7A exepression in A549/DDP cells only partially reversed the resistance to DDP but not mostly.

The intracellular amounts of DDP in A549/DDP cells was much lower than in the parental A549 cells, suggesting the platinum resistance of A549/DDP is due to decreased drug accumulation. SiRNA-knockdown ATP7A in A549/DDP cells increased the intracellular amounts of DDP. These results indicate that the platinum-resistance in A549/DDP cells is mediated by decreasing drug accumulation of ATP7A. Overexpression of ATP7A in A549/DDP cells might pump more platinum into trans-Golgi network, thus decrease cellular platinum concentration and keep them from accessing their key cytotoxic targets in the nucleus, resulting in DDPresistance. Recently the copper transporters have been demonstrated to be involved in platinum-resistance in some cancers. Samimi G demonstrated that overexpression of ATP7A in human ovarian carcinoma cells confered resistance to DDP, CBDCA and L-OHP by sequestering platinum analogues in intracellular compartments and preventing their reaction with nuclear DNA [10]. Plasencia C also reported that ATP7A overexpression in L-OHP resistant colorectal cancer cells [25]. Consistent with those reports, our results demonstrated that the platinum resistance is associated with ATP7A in lung cancer cell. To our knowledge, this is the first report about ATP7A related to platinum-resistance in NSCLC.

In clinical, we found that $41.6 \%(37 / 89)$ of NSCLC patients aberrantly expressed ATP7A. However, ATP7A protein was not detected in tumor adjacent stroma nor normal lung tissue. This suggested that ATP7A might be involved in transformation of a normal differentiated cell to a malignant tumor cell. Compared with the ATP7A-negative patients, ATP7A-positive patients had a inferiorly histological grade $(P=0.039)$, inferior response to platinum-basing chemotherapy $(P=0.001)$ and poorer OS $(P=0.021)$. Cox's proportional hazards model analysis showed that ATP7A expression was an independently prognostic factor of survival. Some studies in ovarian cancer showed similar results that increased expression of ATP7A mediated resistance to platinum derivatives in cancer cells and was associated with poor survival in ovarian cancer patients during platinum drug-based treatments $[10,11]$. 


\section{Conclusions}

Our results demostrated that overexpression of copper efflux transporter ATP7A was responsible for platinum resistance in A549/DDP cells. These results indicated that ATP7A expression assessed by immunohistochemistry could be a chemo-resistant marker and a negative prognostic factor for survival in NSCLC patients treated with platinum-based chemotherapy, providing a basis for a better utilization of platinum-based antitumor agents and thereby improving the survival of NSCLC patients.

\section{Abbreviations \\ ATP7A: Adenosine triphosphatase; NSCLC: Non-small cell lung cancer; RECIST: Response Evaluation Criteria in Solid Tumors; ABC: ATP-binding cassette; MDR: Multidrug resistance; MRP1: Multidrug resistance-associated protein 1; LRP: Lung resistance protein; ABCG2: ATP-binding cassette sub-family G member 2 protein; GST: GSH-S-transferase; DNA polß: DNA polymerase beta; PI: Propidium iodide; PS: Performance status; OS: Overall survival. RT-PCR: Reverse Transcriptase-Polymerase Chain Reaction; CEA: Carcinoembryonic Antigen.}

\section{Acknowledgements}

We thank Prof. Li-wu Fu (State Key Laboratory of Oncology in Southern China) for the A549 and A549/DDP cell lines and helpful discussions.

\section{Author details}

${ }^{1}$ State Key Laboratory of Oncology in South China, Sun Yat-Sen University Cancer Center, Guangzhou 510060, China. ²Department of Medical Oncology, Sun Yat-Sen University Cancer Center, 651 Dong Feng Road East, Guangzhou 510060, China. ${ }^{3}$ Department of Medical Oncology, Dongguan People's Hospital, Dongguan523059, Guangdong, China.

\section{Authors' contributions}

LZH and QMZ carried out the real-time PCR, participated in the clinical data collecting of the gastric carcinoma patients and drafted the manuscript. ZZL carried out the MTT and immunoblotting. LHY participated in the blood sample collecting. WWJ carried out the flow cytometry. WF performed the statistical analysis. WZQ and ZDS participated in the design of the study. $\mathrm{LYH}$ drafted the manuscript and participated in the statistical analysis. $\mathrm{XRH}$ conceived of the study, and participated in its design and coordination and helped to draft the manuscript. All authors read and approved the final manuscript.

\section{Competing interests}

We have no financial or personal relationships with other people or organizations that would bias our work. No benefits in any form have been received or will be received from a commercial party related directly or indirectly to the subject of our article.

Received: 14 November 2011 Accepted: 3 February 2012

Published: 3 February 2012

\section{References}

1. Rinaldi $M$, Cauchi C, Gridelli C: First line chemotherapy in advanced or metastatic NSCLC. Ann Oncol 2006, 17(Suppl 5):v64-v67.

2. Stewart DJ: Mechanisms of resistance to cisplatin and carboplatin. Crit Rev Oncol Hematol 2007, 63:12-31.

3. Martin LP, Hamilton TC, Schilder RJ: Platinum resistance: the role of DNA repair pathways. Clin Cancer Res 2008, 14:1291-1295.

4. Cui Y, Konig J, Buchholz JK, Spring H, Leier I, Keppler D: Drug resistance and ATP-dependent conjugate transport mediated by the apical multidrug resistance protein, MRP2, permanently expressed in human and canine cells. Mol Pharmacol 1999, 55:929-937.
5. Safaei R, Katano K, Samimi G, Naerdemann W, Stevenson JL, Rochdi M, Howell SB: Cross-resistance to cisplatin in cells with acquired resistance to copper. Cancer Chemother Pharmacol 2004, 53:239-246.

6. Kuo MT, Chen HH, Song IS, Savaraj N, Ishikawa T: The roles of copper transporters in cisplatin resistance. Cancer Metastasis Rev 2007, 26:71-83.

7. Setty SR, Tenza D, Sviderskaya EV, Bennett DC, Raposo G, Marks MS: Cellspecific ATP7A transport sustains copper-dependent tyrosinase activity in melanosomes. Nature 2008, 454:1142-1146.

8. Nakayama K, Miyazaki K, Kanzaki A, Fukumoto M, Takebayashi Y: Expression and cisplatin sensitivity of copper-transporting P-type adenosine triphosphatase (ATP7B) in human solid carcinoma cell lines. Oncol Rep 2001, 8:1285-1287.

9. Komatsu M, Sumizawa T, Mutoh M, Chen ZS, Terada K, Furukawa T, Yang XL, Gao H, Miura N, Sugiyama T, Akiyama S: Copper-transporting Ptype adenosine triphosphatase (ATP7B) is associated with cisplatin resistance. Cancer Res 2000, 60:1312-1316.

10. Samimi G, Safaei R, Katano K, Holzer AK, Rochdi M, Tomioka M, Goodman M, Howell SB: Increased expression of the copper efflux transporter ATP7A mediates resistance to cisplatin, carboplatin, and oxaliplatin in ovarian cancer cells. Clin Cancer Res 2004, 10:4661-4669.

11. Samimi G, Varki NM, Wilczynski S, Safaei R, Alberts DS, Howell SB: Increase in expression of the copper transporter ATP7A during platinum drugbased treatment is associated with poor survival in ovarian cancer patients. Clin Cancer Res 2003, 9:5853-5859.

12. Wu C, Wangpaichitr M, Feun L, Kuo MT, Robles C, Lampidis T, Savaraj N: Overcoming cisplatin resistance by $\mathrm{mTOR}$ inhibitor in lung cancer. $\mathrm{Mol}$ Cancer 2005, 4:25.

13. Wen J, Zheng B, Hu Y, Zhang X, Yang H, Luo KJ, Zhang X, Li YF, Fu JH: Establishment and biological analysis of the EC109/CDDP multidrugresistant esophageal squamous cell carcinoma cell line. Oncol Reports 2009, 22:65-71.

14. Wang L, Sun J, Li YQ, Chen ZS, Akiyama S, Xian LJ: Reversal effect of BMcyclin 1 on multidrug resistance in C-A120 cells. Anticancer Drugs 2007, 18:1015-1021.

15. Lin C, Wu Z, Lin X, Yu C, Shi T, Zeng Y, Wang X, Li J, Song L: Knockdown of FLOT1 impairs cell proliferation and tumorigenicity in breast cancer through upregulation of FOXO3a. Clin Cancer Res 2011, 17:3089-3099.

16. Afton SE, Caruso JA, Britigan BE, Qin Z: Copper egress is induced by PMA in human THP-1 monocytic cell line. Biometals 2009, 22:531-539.

17. Aida T, Takebayashi Y, Shimizu T, Okamura C, Higasimoto M, Kanzaki A, Nakayama K, Terada K, Sugiyama T, Miyazaki K, et al: Expression of coppertransporting P-type adenosine triphosphatase (ATP7B) as a prognostic factor in human endometrial carcinoma. Gynecol Oncol 2005, 97:41-45.

18. Rixe O, Ortuzar W, Alvarez M, Parker R, Reed E, Paull K, Fojo T: Oxaliplatin, tetraplatin, cisplatin, and carboplatin: spectrum of activity in drugresistant cell lines and in the cell lines of the National Cancer Institute's Anticancer Drug Screen panel. Biochem Pharmacol 1996, 52:1855-1865.

19. Ling V: Multidrug resistance and P-glycoprotein expression. Ann NY Acad Sci 1987, 507:7-8.

20. Colone M, Calcabrini A, Toccacieli L, Bozzuto G, Stringaro A, Gentile M, Cianfriglia M, Ciervo A, Caraglia M, Budillon A, et al: The multidrug transporter P-glycoprotein: a mediator of melanoma invasion. J Invest Dermatol 2008, 128:957-971.

21. Casale F, D'Angelo V, Addeo R, Caraglia M, Crisci S, Rondelli R, Di Tullio MT, Indolfi P: P-glycoprotein 170 expression and function as an adverse independent prognostic factor in childhood acute lymphoblastic leukemia. Oncol Rep 2004, 12:1201-1207.

22. Di Martino MT, Arbitrio M, Leone E, Guzzi PH, Rotundo MS, Ciliberto D, Tomaino V, Fabiani F, Talarico D, Sperlongano P, et al: Single nucleotide polymorphisms of $A B C C 5$ and $A B C G 1$ transporter genes correlate to irinotecan-associated gastrointestinal toxicity in colorectal cancer patients: a DMET microarray profiling study. Cancer Biol Ther 2011, 12:780-787.

23. Chaney SG, Campbell SL, Bassett E, Wu Y: Recognition and processing of cisplatin- and oxaliplatin-DNA adducts. Crit Rev Oncol Hematol 2005, 53:3-11.

24. Allday MJ, Inman GJ, Crawford DH, Farrell PJ: DNA damage in human B cells can induce apoptosis, proceeding from G1/S when p53 is transactivation competent and G2/M when it is transactivation defective. EMBO J 1995, 14:4994-5005. 
25. Plasencia C, Martinez-Balibrea E, Martinez-Cardus A, Quinn DI, Abad A, Neamati $\mathrm{N}$ : Expression analysis of genes involved in oxaliplatin response and development of oxaliplatin-resistant HT29 colon cancer cells. Int J Oncol 2006, 29:225-235.

doi:10.1186/1479-5876-10-21

Cite this article as: Li et al:: Copper-transporting P-type adenosine

triphosphatase (ATP7A) is associated with platinum-resistance in non-small cell lung cancer (NSCLC). Journal of Translational Medicine 2012 10:21.

Submit your next manuscript to BioMed Central and take full advantage of:

- Convenient online submission

- Thorough peer review

- No space constraints or color figure charges

- Immediate publication on acceptance

- Inclusion in PubMed, CAS, Scopus and Google Scholar

- Research which is freely available for redistribution

Submit your manuscript at www.biomedcentral.com/submit 